\title{
Temperature variations over the past millennium on the Tibetan Plateau revealed by four ice cores
}

\author{
YAO Tandong, ${ }^{1,2}$ DUAN Keqin, ${ }^{1,2}$ L.G. THOMPSON, ${ }^{1,3}$ WANG Ninglian, ${ }^{1,2}$ \\ TIAN Lide,, ${ }^{1,2}$ XU Baiqing, ${ }^{1,2}$ WANG Youqing, ${ }^{1,2} \mathrm{YU}$ Wusheng ${ }^{1,2}$ \\ ${ }^{1}$ Institute of Tibetan Plateau Research, Chinese Academy of Sciences, Beijing 100085, China \\ E-mail: tdyao@itpcas.ac.cn \\ ${ }^{2}$ Cold and Arid Regions Environmental and Engineering Research Institute, Chinese Academy of Sciences, \\ Lanzhou 730000, China \\ ${ }^{3}$ Byrd Polar Research Center, The Ohio State University, 1090 Carmack Road, Columbus, \\ $\mathrm{OH}$ 43210-1002, USA
}

\begin{abstract}
Temperature variation on the Tibetan Plateau over the last 1000 years has been inferred using a composite $\delta^{18} \mathrm{O}$ record from four ice cores. Data from a new ice core recovered from the Puruogangri ice field in the central Tibetan Plateau are combined with those from three other cores (Dunde, Guliya and Dasuopu) recovered previously. The ice-core $\delta^{18} \mathrm{O}$ composite record indicates that the temperature change on the whole Tibetan Plateau is similar to that in the Northern Hemisphere on multi-decadal timescales except that there is no decreasing trend from AD 1000 to the late 19th century. The $\delta^{18} \mathrm{O}$ composite record from the northern Tibetan Plateau, however, indicates a cooling trend from AD 1000 to the late 19th century, which is more consistent with the Northern Hemisphere temperature reconstruction. The $\delta^{18} \mathrm{O}$ composite record reveals the existence of the Medieval Warm Period and the Little Ice Age (LIA) on the Tibetan Plateau. However, on the Tibetan Plateau the LIA is not the coldest period during the last millennium as in other regions in the Northern Hemisphere. The present study indicates that the 20th-century warming on the Tibetan Plateau is abrupt, and is warmer than at any time during the past 1000 years.
\end{abstract}

\section{INTRODUCTION}

Instrumental records show that global mean temperature has increased by $0.6 \pm 0.2^{\circ} \mathrm{C}$ over the last century, with the 1990s being the warmest decade since the start of instrumental records in 1856 (Jones and Moberg, 2003). However, the magnitude of the warming is not uniform in different regions (Yadav and others, 2004). Due to incomplete understanding of natural climate variability, our ability to predict future climate change on a regional scale is still limited (Hulme and others, 1998). In recent years, highresolution records such as ice cores, tree rings, corals, lake sediments and historic documents have become the main sources for studying the variations of temperature in the past 1000 years (Mann and others, 1999; Jones and others, 2001; Mann and Jones, 2003; Moberg and others, 2005). However, our view of past climatic conditions is still seriously biased by the shortage of data (Bradley and Jones, 1993; Hughes and Diaz, 1994; Mann and others, 1995), and thus cannot be used to test and validate climate models on a global scale. For example, recent temperature reconstruction using tree-ring data (Esper and others, 2002), and tree-ring data as well as lake and ocean sediment data (Moberg and others, 2005), disagrees with Mann and others' (1999) result on multi-centennial timescales, suggesting we need more independent regional temperature reconstructions based on improved proxy records (Keith and Timothy, 2002).

The Tibetan Plateau drives the intensity of Asian monsoon circulation and influences global circulation patterns (Yanai and Li, 1994; Li and Yanai, 1996; Ueda and Yasunari, 1998; Webster, and others, 1998). However, climate at high altitudes of the Tibetan Plateau is poorly known due to the logistical difficulties in maintaining observational networks.
The existing natural records from ice cores, tree rings and lake sediments (Wang and others, 1983; Yao and Thompson, 1992; Thompson and others, 1993, 1997, 2000, 2003; Yao and others, 1996b, 1999; Tang and others, 2000; Shen and others, 2001; Zhu and others, 2001) show that climate varied differently from region to region across the Tibetan Plateau. Although Mann and others (1999) and Jones and Moberg (2003) present the most comprehensive temperature reconstructions of the past 1000 years for the Northern and Southern Hemisphere, the Tibetan Plateau is not well covered. Independent temperature reconstruction for the Tibetan Plateau over the past millennium is therefore necessary to assess the climatic change in this region. Yang and others (2003) reconstructed temperature for the Tibetan Plateau using ice-core, tree-ring, lake sediment and documentary records; however, there is a disadvantage in this type of multi-proxy approach due to the difference in resolution (from 1 year to multi-centennial) and in the different significance of proxies resulting from different processes. Therefore, the dating and significance of records using multi-proxies limited understanding of climatic changes. Since 1987, several deep ice cores have been drilled on the Tibetan Plateau, and ice-core $\delta^{18} \mathrm{O}$ is considered as a proxy of temperature (Yao and others, 1996a). In 2000, an ice core was recovered on the Puruogangri ice field, in the central Tibetan Plateau. This core is considered as a bridge for the understanding of climate change in the central Tibetan Plateau, where there was previously no long paleoclimate record, and other regions. With this new ice core, it is possible to use a single proxy to infer large-scale spatial temperature change by combining the Puruogangri ice-core $\delta^{18} \mathrm{O}$ record with other existing ice-core $\delta^{18} \mathrm{O}$ records. Here we report on the 


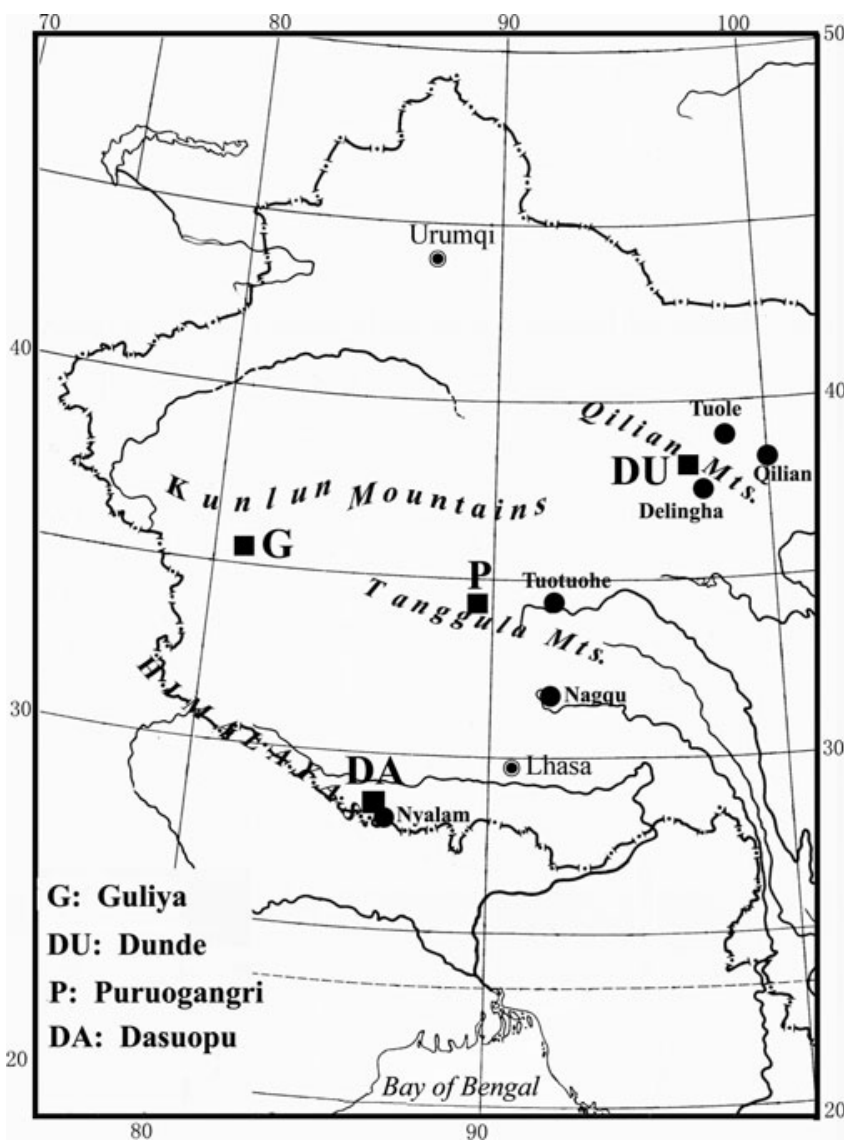

Fig. 1. Locations of the four ice cores on the Tibetan Plateau used in this study.

interpretation in terms of temperature evolution of a 1000 year $\delta^{18} \mathrm{O}$ composite record on the Tibetan Plateau based on four ice-core records.

\section{DATA}

Figure 1 shows the sites of the four Tibetan Plateau ice cores used in this study and indicates the good geographical distribution, which covers most of the plateau. It particularly illustrates the importance of the newly recovered Puruogangri ice-field core recovered in 2000. Situated in the central Tibetan Plateau, the Puruogangri ice field $\left(33^{\circ} 44^{\prime}-34^{\circ} 03^{\prime} \mathrm{N}\right.$, $89^{\circ} 00^{\prime}-89^{\circ} 20^{\prime} \mathrm{E}$ ) is the largest ice field in the mid-latitudes, with a total area of $>400 \mathrm{~km}^{2}$. In 2000, five cores were drilled at the summit of the Puruogangri ice field and were taken in a frozen state to the Laboratory of Ice Core and Cold Regions Environment, Lanzhou, China, and the Byrd Polar Research Center, Columbus, OH, USA. The $213 \mathrm{~m}$ ice core (the longest of the five ice cores; Table 1) was cut into $3-5 \mathrm{~cm}$ samples and analyzed over its entire length for oxygen isotopic ratio $\left(\delta^{18} \mathrm{O}\right)$. The upper $102 \mathrm{~m}$ of the Puruogangri ice core (covering the last 1000 years) was dated by counting annual layers of insoluble dust and $\delta^{18} \mathrm{O}$ (Thompson and others, 2006; Yao and others, 2006).

The other cores, Dunde, Guliya and Dasuopu, were recovered in the 1980s and 1990s (Table 1). The $138 \mathrm{~m}$ long Dunde ice core, drilled at $5325 \mathrm{ma.s.l}$. on the Dunde ice cap $\left(38^{\circ} 06^{\prime} \mathrm{N}, 96^{\circ} 25^{\prime} \mathrm{E}\right)$ in 1987 , provided the first ice-core record from the Tibetan Plateau, which contained a 30000 year $\delta^{18} \mathrm{O}$ record with an annually reconstructed
Table 1. Details of the four ice cores used in this study

\begin{tabular}{|c|c|c|c|c|c|c|}
\hline \multirow[t]{2}{*}{ Ice core } & \multirow[t]{2}{*}{$\begin{array}{c}\text { Drilling } \\
\text { year }\end{array}$} & \multirow[t]{2}{*}{ Lat. } & \multirow[t]{2}{*}{ Long. } & \multirow{2}{*}{$\begin{array}{l}\text { Length } \\
\text { m }\end{array}$} & \multirow{2}{*}{$\begin{array}{c}\text { Elevation } \\
\text { ma.s.l. }\end{array}$} & \multirow{2}{*}{$\begin{array}{c}\delta^{18} \mathrm{O} \\
\text { mean* } \\
\%\end{array}$} \\
\hline & & & & & & \\
\hline Dunde & 1987 & $38^{\circ} 06^{\prime} \mathrm{N}$ & $96^{\circ} 25^{\prime} \mathrm{E}$ & 138 & 5325 & -10.8 \\
\hline Guliya & 1992 & $35^{\circ} 17^{\prime} \mathrm{N}$ & $81^{\circ} 29^{\prime} \mathrm{E}$ & 308 & 6200 & -15.5 \\
\hline Puruogangri & 2000 & $33^{\circ} 55^{\prime} \mathrm{N}$ & $89^{\circ} 05^{\prime} \mathrm{E}$ & 213 & 6000 & -15.8 \\
\hline Dasuopu & 1997 & $28^{\circ} 23^{\prime} \mathrm{N}$ & $85^{\circ} 43^{\prime} \mathrm{E}$ & 168 & 7200 & -20.3 \\
\hline
\end{tabular}

*Values are averages of past 1000 years.

Little Ice Age (LIA) record (Thompson and others, 1989; Yao and Thompson, 1992). The $308 \mathrm{~m}$ long Guliya ice core $\left(35^{\circ} 17^{\prime} \mathrm{N}, 81^{\circ} 29^{\prime} \mathrm{E}\right)$, drilled in early 1992, displays the longest ice-core record from the Tibetan Plateau (Thompson and others, 1997). The Dasuopu ice core, from an elevation of about $7000 \mathrm{~m}$, drilled in 1997 in the central Himalaya, is one of two ice cores recovered at the highest altitude (7200 ma.s.l.) in the world (the other is the Muztagata ice core and the results are under analyses). It is considered to provide information on long-term variations of the Indian monsoon (Thompson and others, 2000; Yao and others, 2002; Duan and others, 2004). The Dunde, Guliya and Puruogangri ice cores have been annually dated back to AD 1000. The Dasuopu ice core has only been annually dated back to AD 1440. For the Dasuopu ice core, only decadal averages are available from AD 1439 to 1000 (Thompson and others, 2000).

\section{$\delta^{18}$ O INTERPRETATION IN ICE CORES}

Both empirical data and model studies have shown that $\delta^{18} \mathrm{O}$ in polar ice cores can be interpreted in terms of local temperature (Dansgaard, 1964; Rozanski and others, 1993). Before 1989, however, there was little knowledge of $\delta^{18} \mathrm{O}$ variability with temperature on the Tibetan Plateau. Beginning with the establishment of monitoring stations in 1989, stable-isotope data for precipitation on the Tibetan Plateau are accumulating, and our understanding of this issue is progressing. Our study indicates differences in $\delta^{18} \mathrm{O}$ of precipitation between the northern and southern Tibetan Plateau on the seasonal scale. In the northern Tibetan Plateau the correlation between $\delta^{18} \mathrm{O}$ and air temperature is obvious on a seasonal scale (Yao and others, 1996a, 1999; Tian and others, 2003). In the southern Tibetan Plateau, strong monsoon activity results in high precipitation and more depleted $\delta^{18} \mathrm{O}$. This precipitation 'amount effect' results in a poor $\delta^{18} \mathrm{O}$-temperature relationship at both seasonal and annual scales (Tian and others, 2003). $\delta^{18} \mathrm{O}$ is therefore not a temperature signal, but a monsoon signal, on seasonal and annual timescales. However, it is still a temperature signal at longer than annual timescales since it reflects sea surface processes on longer timescales (Thompson and others, 2000, 2003). This is demonstrated by the Dasuopu $\delta^{18} \mathrm{O}$ record which is poorly correlated with precipitation on an annual timescale but is well correlated with the air temperature at Xigaze station near Dasuopu glacier (Thompson, 2000; Thompson and others, 2000) on longer timescales.

The Dunde and Guliya $\delta^{18} \mathrm{O}$ records are shown to be temperature signals by the relationship between $\delta^{18} \mathrm{O}$ in 


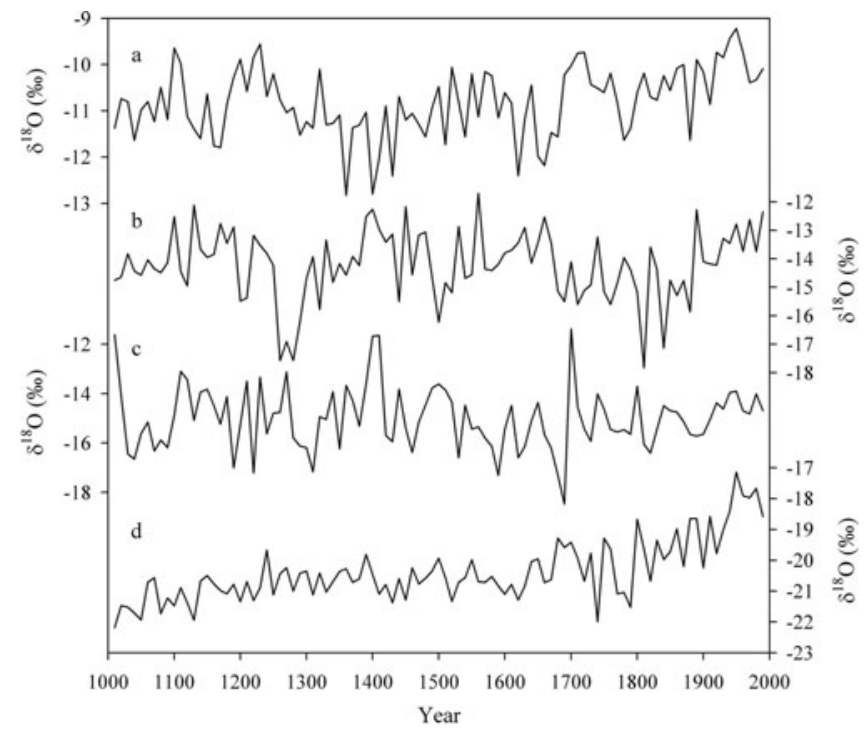

Fig. 2. Decadal $\delta^{18} \mathrm{O}$ records from the Dunde ice core (a), Guliya ice core (b), Puruogangri ice core (c) and Dasuopu ice core (d) on the Tibetan Plateau in the last millennium.

precipitation and air temperature from nearby meteorological stations (Yao and others, 1991; Lin and others, 1995; Tian and others, 2003). In the middle of the Tibetan Plateau, the Puruogangri record shows the monsoon continues to cause a weak correlation between $\delta^{18} \mathrm{O}$ and temperature on the precipitation event timescale (Tian and others, 2003). On a monthly timescale, however, a significant $\delta^{18} \mathrm{O}-$ temperature relationship exists (Yao and others, 1996a; Tian and others, 2003). Thus the $\delta^{18} \mathrm{O}$ record in the Puruogangri ice core is a temperature proxy on annual timescales as shown by a recent study correlating the $\delta^{18} \mathrm{O}$ record in the core and temperature from a nearby meteorological station (Yao and others, 2006).

\section{METHOD}

Based on the above analysis, the $\delta^{18} \mathrm{O}$ records in the four ice cores reflect air-temperature variability in the western, northern, southern and central Tibetan Plateau. Given the possible uncertainties in annual dating of the ice cores and to remove the seasonal variability of $\delta^{18} \mathrm{O}$, we take 10 year averages of the $\delta^{18} \mathrm{O}$ records for all four ice cores. To infer a temperature interpretation, a composite record was constructed using the four ice-core records. Each temperature record was standardized by removal of the long-term mean and division by the standard deviation. Theoretically, a composite series should be formed from area-weighted combinations of the individual standardized time series, but on the Tibetan Plateau most of the meteorological stations are located in the east and few in the west. Therefore there is no reliable method to divide the Tibetan Plateau into subregions for combining the ice-core record with specific area weights. As shown in Figure 1, the sites of the four ice cores have a good geographical distribution, so an equal area weight was given to each core to produce the composite record. The $\delta^{18} \mathrm{O}$ composite record based on the four ice cores does not provide numerical values of temperature variation but indicates the relative amplitude of temperature change.

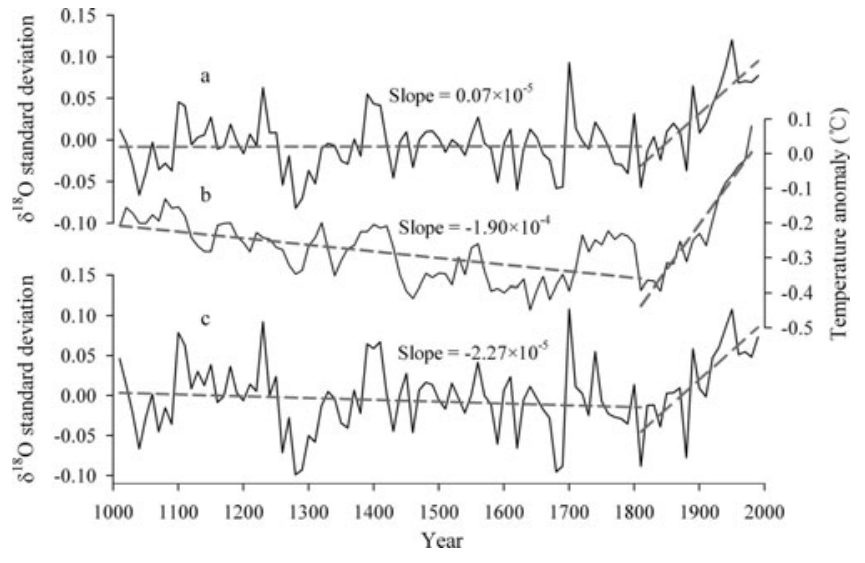

Fig. 3. Comparison of (a) decadal means of $\delta^{18} \mathrm{O}$ composite record for the Tibetan Plateau from four ice cores; (b) the Northern Hemisphere temperature reconstructed by Mann and others (1999); and (c) $\delta^{18} \mathrm{O}$ composite record based on the three ice cores on the northern Tibetan Plateau. Dashed lines are trend lines.

\section{RESULTS AND DISCUSSION}

Figure 2 shows the decadal $\delta^{18} \mathrm{O}$ records of the four ice cores over the last millennium. It is clear that there is considerable regional variability in these records. The main differences are that average $\delta^{18} \mathrm{O}$ increases northward and decreases with increasing core site altitude. For example, the Dasuopu ice core, collected from an elevation of $7200 \mathrm{~m}$, has the lowest mean $\delta^{18} \mathrm{O}$ value of $-20.3 \%$. In comparison, the Puruogangri ice core (recovered at $6000 \mathrm{ma.s.l}$.) and the Guliya ice core (recovered at 6200 ma.s.l.) have higher mean $\delta^{18} \mathrm{O}$ values of $-15.8 \%$ and $-15.5 \%$ respectively (Table 1 ). Despite the similar altitudes of the Puruogangri and Guliya ice cores, $\delta^{18} \mathrm{O}$ values in the former are slightly lower than in the latter, which may indicate the influence of the large ice-field cooling on the latter. Collected from a much lower altitude of $5300 \mathrm{~m}$, the Dunde ice core has the highest mean $\delta^{18} \mathrm{O}$ value of $-10.8 \%$ (Table 1 ).

The four ice cores' $\delta^{18} \mathrm{O}$ composite record (Fig. 3a) indicates the temperature variation of the whole Tibetan Plateau. It is clear that inter-decadal fluctuations dominate the past 1000 years. The period from approximately AD 1090 to 1250 , equivalent to the Medieval Warm Period (MWP) in Europe (AD 1000-1300), is observed to be moderately warmer than the periods both preceding and following it. This warming and those during AD 1380-1420 and 16901750 are dwarfed by late-20th-century warming which is observed to be unprecedented for the last millennium. The period AD 1570-1880, which appears to have been relatively cold compared to the present, represents the LIA on the Tibetan Plateau. However, the coldest period observed during the last millennium is AD 1250-1370.

Figure $3 \mathrm{a}$ and $\mathrm{b}$ present a comparison between the four Tibetan ice cores' $\delta^{18} \mathrm{O}$ composite record and the Northern Hemisphere temperature reconstruction over the period AD 1000-1980 (Mann and others, 1999). The correlation coefficient of the two series is 0.37 at $99 \%$ confidence level, which shows that over shorter periods the two series are almost synchronous. Both the Tibetan Plateau and the Northern Hemisphere have seen an abrupt and unprecedented increase in temperature from the late 19th century to the present. 
In spite of the overall similarity of the two series, there are some remarkable differences. The main disagreement is largely confined to trends of both series. As shown in Figure $3 a$ and $b$, there is an evident temperature decrease trend (slope $=-1.90 \times 10^{-4} \mathrm{a}^{-1}$ ) for the Northern Hemisphere from $\mathrm{AD} 1000$ to the late 19th century, whereas there is no such trend in the composite record for the Tibetan Plateau during the same period. However, this is not so apparent in the more recent reconstruction (Moberg and others, 2005). Another obvious difference is that the LIA appears to be less pronounced in the Tibetan Plateau compared to the Northern Hemisphere.

Although $\delta^{18} \mathrm{O}$ records in the Dunde, Guliya and Puruogangri ice cores are mainly controlled by temperature, the significance of the $\delta^{18} \mathrm{O}$ record in the Dasuopu ice core is rather complex because of the monsoon influence. The $\delta^{18} \mathrm{O}$ record in the Dasuopu ice core is considered as a temperature proxy over multi-decadal timescales. It is, however, important to consider at times that the temperature proxy may contain non-temperature influences. In Figure 3c we show a composite record based on $\delta^{18} \mathrm{O}$ in the three cores located in the northern Tibetan Plateau Dunde, Guliya and Puruogangri - where temperature dominates the $\delta^{18} \mathrm{O}$ signal. This composite record indicates that the 20th-century warming is also abrupt and exceptional. Unlike the composite record based on the four ice cores, this one shows an evident temperature decrease trend (slope $=-2.27 \times 10^{-5} \mathrm{a}^{-1}$ ) from $\mathrm{AD} 1000$ to 1810 , which is similar to Mann and others' (1999) temperature reconstruction for the Northern Hemisphere. Another remarkable difference in the two $\delta^{18} \mathrm{O}$ composite records between the three northern ice cores and all four ice cores is that the MWP and the LIA are warmer in the former than in the latter. In summary, both series show agreement on multidecadal timescales, suggesting that cold or warm periods on the Tibetan Plateau are almost synchronous with those in the Northern Hemisphere (Fig. 3).

A number of studies have reconstructed Northern Hemisphere temperature for the last millennium using different proxy data and methods. These in turn, have resulted in discrepancies in temperature reconstructions (Mann and others, 1999; Esper and others, 2002; Keith and Timothy, 2002; Moberg and others, 2005). This means that we need more independent reconstructions based on improved single proxy records. Our ice-core records provide a history of climate change for the Tibetan Plateau over the last millennium, which supplements the Northern Hemisphere reconstruction. Moreover, our $\delta^{18} \mathrm{O}$ composite record temperature interpretation for the Tibetan Plateau provides a test of the climate model's response to different forcings. For example, the Tibetan Plateau is far from human activity relative to other regions in the tropics and subtropics, and climate change on the Tibetan Plateau should respond more directly to natural forcing, and any disturbance from human activity might be sensibly detected on the Tibetan Plateau. The temperature reconstruction for the Tibetan Plateau shows the abrupt and exceptional climatic warming in the 20th century compared to other warm periods in the last millennium, which might indicate that anthropogenic forcing is responsible for the climate warming on the Tibetan Plateau since the industrial revolution. The greatest promise of these ice-core records is that they will provide a much-needed long-term perspective over many millennia.

\section{CONCLUSIONS}

The temperature reconstruction for the Tibetan Plateau inferred from a composite of four ice-core $\delta^{18} \mathrm{O}$ records demonstrates evidence of climate warming during the last millennium. The $\delta^{18} \mathrm{O}$ composite record shows a strong increase in temperature during the late 19th and 20th centuries. The $\delta^{18} \mathrm{O}$ composite record also addressed the existence of the MWP and the LIA on the Tibetan Plateau. The LIA on the Tibetan Plateau is, however, not the coldest period during the past 1000 years as it is in other regions in the Northern Hemisphere. It is only a period which is colder than the present.

\section{ACKNOWLEDGEMENTS}

This work was supported by the Ministry of Science and Technology of the People's Republic of China (2005CB422004), the Collective Innovation of the National Natural Science Foundation of China (40121101), and the National Natural Science Foundation of China (40571039).

\section{REFERENCES}

Bradley, R.S. and P.D. Jones. 1993. 'Little Ice Age' summer temperature variations: their nature and relevance to recent global warming trends. Holocene, 3(4), 367-376.

Dansgaard, W. 1964. Stable isotopes in precipitation. Tellus, 16(4), 436-468.

Duan, K., T. Yao and L.G. Thompson. 2004. Low-frequency of southern Asian monsoon variability using a 295-year record from the Dasuopu ice core in the central Himalayas. Geophys. Res. Lett., 31(16), L16209. (10.1029/2004GL020015.)

Esper, J., E.R. Cook and F.H. Schweingruber. 2002. Low-frequency signals in long tree-ring chronologies for reconstructing past temperature variability. Science, 295(5563), 2250-2253.

Hughes, M.K. and H.F. Diaz. 1994. Was there a 'Medieval Warm Period', and if so, where and when? Climatic Change, 26(2-3), 109-142.

Hulme, M., T.J. Osborn and T.C. Johns. 1998. Precipitation sensitivity to global warming: Comparison of observations with HadCM2 simulations. Geophys. Res. Lett., 25(17), 3379-3382.

Jones, P.D. and A. Moberg. 2003. Hemispheric and large-scale surface air temperature variations: an extensive revision and an update to 2001. J. Climate, 16(2), 206-223.

Jones, P.D., T.J. Osborn and K.R. Briffa. 2001. The evolution of climate over the last millennium. Science, 292(5517), 662-667.

Keith, R.B. and J.O. Timothy. 2002. Blowing hot and cold. Science, 295(5563), 2227-2228

Li, C. and M. Yanai. 1996. The onset and interannual variability of the Asian summer monsoon in relation to land-sea thermal contrast. J. Climate, 9(2), 358-375.

Lin, P.N., L.G. Thompson, M.E. Davis and E. Mosley-Thompson. 1995. 1000 years of climatic change in China: ice-core $\delta^{18} \mathrm{O}$ evidence. Ann. Glaciol., 21, 189-195.

Mann, M.E. and P.D. Jones. 2003. Global surface temperatures over the past two millennia. Geophys. Res. Lett., 30(15), 1820. (10.1029/2003GL017814.)

Mann, M.E., J. Park and R.S. Bradley. 1995. Global interdecadal and century-scale climate oscillations during the past five centuries. Nature, 378(6554), 266-270.

Mann, M.E., R.S. Bradley and M.K. Hughes. 1999. Northern hemisphere temperatures during the past millennium: inferences, uncertainties and limitations. Geophys. Res. Lett., 26(6), 759-762.

Moberg, A., D.M. Sonechkin, K. Holmgren, N.M. Datsenko and W. Karlén. 2005. Highly variable Northern Hemisphere 
temperatures reconstructed from low- and high-resolution proxy data. Nature, 433(7026), 613-617.

Rozanski, K., L. Araguás-Araguás and R. Gonfiantini. 1993. Isotopic patterns in modern global precipitation. In Swart, P.K., K.C. Lohmann, J.A. McKenzie and S. Savin, eds. Climate change in continental isotopic records. Washington, DC, American Geophysical Union, 1-36.

Shen, J., E.L. Zhang and W.L. Xia. 2001. Records from lake sediments of the Qinghai lake to mirror climatic and environmental changes of the past about 1000 years. Quat. Sci., 21(6), 508-513.

Tang, L.Y., C.M. Shen, K.B. Liu and J.T. Overpeck. 2000. Changes in South Asian monsoon: new high-resolution paleoclimatic records from Tibet, China. Chinese Sci. Bull., 45, 87-91.

Thompson, L.G. 2000. Ice core evidence for climate change in the Tropics: implications for our future. Quat. Sci. Rev., 19(1-5), 19-35.

Thompson, L.G. and 9 others. 1989. Holocene-Late Pleistocene climatic ice core records from Qinghai-Tibetan Plateau. Science, 246(4929), 474-477.

Thompson, L.G. and 6 others. 1993. "Recent warming": ice core evidence from tropical ice cores with emphasis on central Asia. Global Planet. Change, 7(1-3), 145-156.

Thompson, L.G. and 9 others. 1997. Tropical climate instability: the last glacial cycle from a Qinghai-Tibetan ice core. Science, 276(5320), 1821-1825.

Thompson, L.G., T. Yao, E. Mosley-Thompson, M.E. Davis, K.A. Henderson and P. Lin. 2000. A high-resolution millennial record of the south Asian monsoon from Himalayan ice cores. Science, 289(5486), 1916-1919.

Thompson, L.G., E. Mosley-Thompson, M.E. Davis, P.N. Lin, K. Henderson and T.A. Mashiotta. 2003. Tropical glacier and ice core evidence of climate change on annual to millennial timescales. Climatic Change, 59(1-2), 137-155.

Thompson, L.G. and 7 others. 2006. Holocene climate variability archived in the Purugangri ice cap on the central Tibetan Plateau. Ann. Glaciol., 43, 61-69.

Tian, L.D. and 7 others. 2003. Oxygen-18 concentrations in recent precipitation and ice cores on the Tibetan Plateau. J. Geophys. Res., 108(D9), 4293-4302.

Ueda, H. and T. Yasunari. 1998. Role of warming over the Tibetan Plateau in early onset of the summer monsoon over the Bay of Bengal and the South China Sea. J. Meteorol. Soc. Japan, 76(1), 1-12.
Wang, Y., G. Liu, X. Zhang and C. Li. 1983. The relationships between tree rings of Qilianshan juniper and climatic change and glacial activity during the past 1000 years in China. Chinese Sci. Bull., 28(12), 1647-1652.

Webster, P.J. and 6 others. 1998. Monsoons: processes, predictability, and the prospects for prediction. J. Geophys. Res., 103(C7), 14,451-14,510.

Yadav, R.R., W.-K. Park, J. Singh and B. Dubey. 2004. Do the western Himalayas defy global warming? Geophys. Res. Lett., 31(17), L17201. (10.1029/2004GL020201.)

Yanai, M. and C. Li. 1994. Mechanism of heating and the boundary layer over the Tibetan Plateau. Mon. Weather Rev., 122(2), 305-323.

Yang, B., B. Achim and Y. Shi. 2003. Late Holocene temperature fluctuations on the Tibetan Plateau. Quat. Sci. Rev., 22(21-22), 2335-2344.

Yao, T. and L.G. Thompson. 1992. Trends and features of climatic changes in the past 5000 years recorded by the Dunde ice core. Ann. Glaciol., 16, 21-24.

Yao, T., Z. Xie, X. Wu and L.G. Thompson. 1991. Climatic change since Little Ice Age recorded by Dunde Ice Cap. Sci. China B, 34(6), 760-767.

Yao, T., L.G. Thompson, E. Mosley-Thompson, Y. Zhihong, Z. Xingping and P.N. Lin. 1996a. Climatological significance of $\delta^{18} \mathrm{O}$ in north Tibetan ice cores. J. Geophys. Res., 101(D23), $29,531-29,537$

Yao, T. and 6 others. 1996b. Variations in temperature and precipitation in the past 2000 years on the Xizang (Tibet) Plateau: Guliya ice core record. Sci. China D, 39(4), 425-433.

Yao, T., V. Masson, J. Jouzel, M. Stiévenard, W. Sun and K. Jiao. 1999. Relationships between $\delta^{18} \mathrm{O}$ in precipitation and surface air temperature in the Urumqi river basin, east Tianshan mountains, China. Geophys. Res. Lett., 26(23), 3,473-3,476.

Yao, T. and 7 others. 2002. Temperature and methane changes over the past 1000 years recorded in Dasuopu glacier (central Himalaya) ice core. Ann. Glaciol., 35, 379-383.

Yao, T. and 7 others. 2006. $\delta^{18} \mathrm{O}$ records from Tibetan ice cores reveal differences in climatic changes. Ann. Glaciol., 43, 1-7.

Zhu, L.P., L. Chen, P.Z. Zhang and B.Y. Li. 2001. Cold/warm fluctuations of the last 13000 years reflected by environmental magnetism in the Chen Co area, southern Tibet. Quat. Sci., 21(6), 520-527. [In Chinese with English summary.] 